\title{
THE ABOMINATION OF DESOLATION IN MATTHEW 24:15
}

\author{
Michael Theophilos
}

The primary research undertaken in this study concerns the meaning of

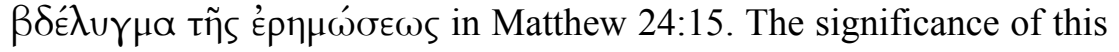
study is to propose a revised model for understanding the enigmatic Matthean phrase through a contextual exegetical approach which gives due weight to Old Testament intertextual prophetic echoes. Because of the primary association of the phrase with Antiochus Epiphanes in the Daniel narrative, commentators have almost exclusively argued for a 'pagan' (contra Jewish) referent in relation to Matthew 24:15 (and synoptic parallels). Alternatively, we argue that within the Matthean narrative, the $\beta \delta \varepsilon \lambda^{\prime} v_{\gamma} \mu \alpha$ (abomination) refers to Israel's covenantal infidelity, particularly her rejection of Jesus as Messianic King, and the Éṕ $\mu \omega \sigma 1 S$ (desolation), is the natural consequence of her disobedience, in this case Yahweh's punishment of Jerusalem through Roman intervention. In this sense, Matthew has been deliberately structured to reflect a Deuteronomistic framework, in that chapters 5-7 and 23 function as blessings and curses respectively. That Matthew's presentation of Jesus' lament over Jerusalem (23:39) seeks to emphasize Israel's culpability in rejecting her Messianic King, provides the appropriate framework for understanding the Matthean apocalypse (ch. 24), which primarily refers to the destruction of Jerusalem through the advent of the Son of Man. The idea that Jerusalem's destruction was engendered by Israel's infidelity is a common motif in first and second century AD Jewish pseudepigraphical material such as The Apocalypse of Abraham, The Syriac Apocalypse of Baruch, The Greek Apocalypse of Baruch, 4 Ezra (2 Esdras 3:3-14), The Book of Biblical Antiquities and Josephus.

This however, raises the thorny issue as to how the language in Matthew 24 should be understood. It is no understatement to suggest that more ink has been spilled on this chapter, with its synoptic parallels, than on any other in the Gospel narratives. Although 
consensus has consistently eluded scholars, there are some clues as to how we should frame the discussion of the vivid 'apocalyptic' descriptions in chapter 24. Given the introductory marker 'As Jesus came out of the temple' and the questions relating to the temple's buildings, there is no reason to suppose the author switches from an 'historical' to an 'end time eschatology' at any point in chapter 24. Even such theologically loaded terms as mapovoía (vv. 3, 27, 37, 39), which have traditionally been interpreted in reference to Jesus' physical return, are more suitably understood with reference to their royal and military motifs. In our discussion we note that one common usage in the Hellenistic world was the use of mapovoía to refer to the visit of a ruler or a high official (Polybius Hist. 18.48.4 of a visit of Antiochus; Polybius Hist 16.25.1ff. of Attalus' entry into Athens in 200 BC; cf. 3 Macc. 3:14-18). Of particular importance, in other extant literature, are the several instances of mapovoría linked specifically with kingship. The term can either be directly associated with kingship,

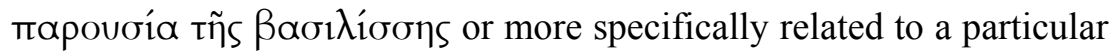

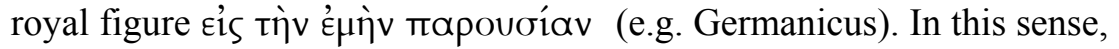
the parousia of the Son of Man refers to the city's destruction through Roman intervention. Furthermore, far from the false-prophets (24:4-5, 11,24 ) indicating any interest in antichrist figures (cf. 2 Thess. 2), substantial parallel can be substantiated from Josephus' 'sign-prophets' (Ant. 20.97; 20.167-168; War 2.258-259; 2.261; 7.438; 18.85-87).

Of particular significance is the attestation of at least one other Matthean contemporary author who describes the military action of the Roman army as 'desert making'. In a well known passage in De vita et moribus Iulii Agricolae, Tacitus records a speech by Calgacus, the leader of the Caledonian Confederacy, which was spoken before the Battle of Mons Graupius in Northern Scotland in AD 83. In it, Calgacus attempts to rouse his troops to fight against the Agricola-led army of Rome. In his last exhortation, Calgacus laments the exploitation of Roman rule and the unquenchable thirst for conquest by stating, 'Auferre, trucidare, rapere, falsis nominibus imperium; atque, ubi solitudinem faciunt, pacem appellant' (They plunder, they slaughter, and they steal: this they falsely name Empire, and where they make a desert, they call it peace [Tacitus Agr. 30.3b-6]).

A similar association is also apparent in the representation of Roman troops as the óetoí of 24:28. While commentators (Luz, Davies and Allison, Mühlethaler) have often taken this image in reference to the 
'second coming' of Jesus, and related it to his visibility and obvious heavenly descent, the connection between 'eagles' and '(Roman) military troops' is able to be established on the basis of 1) Scriptural, 2) numismatic and 3) historical sources (Jos. War 1.648-655; 2:5; War 3.123; cf. 5.48; Ant. 17.151-152, 155, 206).

The so-called 'apocalyptic' language of sun, moon, and falling stars has its primary background in the prophetic literature in reference to descriptions of military invasions (e.g. Isa. 13).

Assessment of the Hebrew Bible's context of our Matthean quotation is significant in several regards. First, that Daniel had a significant influence on the Gospel of Matthew as a whole and chapter 24 in particular. Daniel is presented within the literary context of the Babylonian exile, and chapter 7 functioned as a crucial point in the development of the plot-Israel's enemies are destroyed and 'burnt with fire' (Dan. 7:11) by the coming/going of the Son of Man. Second, there are several indications that the close parallel of Daniel 9 and 11 to the Maccabean history in the Second Century BC identifies the main opponent as Antiochus IV Epiphanes. Further analysis demonstrates that the 'abomination of desolation' is not to be associated with pagan altars erected in honour of Zeus, but rather to the idolatrous and inappropriate behaviour of Antiochus' forces in the temple. Third, analysis of the relevant prophetic literature (Isaiah, Jeremiah, and

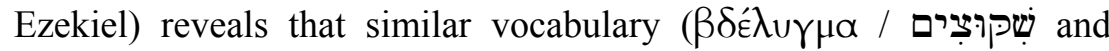

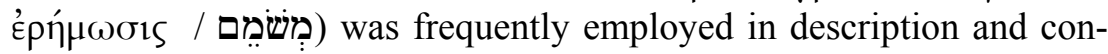
sequence of Israel's covenantal infidelity. And fourth, given that the prophetic literature exhibits such a pervasive and thoroughgoing influence on the book of Daniel, it is argued that this provided Matthew with the theological motivation to ironically employ the Danielic material in description of Jerusalem's destruction in Matthew 24. That this understanding of the 'Son of Man' is consistent with Jewish hopes of redemption is evident not only from the Danielic 'Son of Man', but also finds attestation in pre-first century Jewish literature, namely 1 Enoch and 4 Ezra. Furthermore, a similar theological trajectory is attested in the Qumran literature. In particular, 4Q179 portrays Jerusalem as a 'wilderness' because of the lawlessness and covenantal infidelity of the people. This lawlessness results in the destruction of Jerusalem and is described as a 'desolation'.

This analysis would suggest that the prophetic influence upon

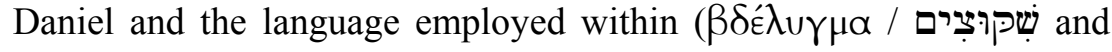




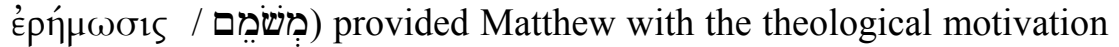
to ironically employ the Danielic material in description of the destruction of Jerusalem in Matthew 24. The ironic element is that Israel has become her own enemy and as such stands under the curses of the covenant and subsequent destruction.

Matthew's rationale for undertaking this typological and metaphorical association may be due to a combination of Plato's pedagogical maxim, Ludwig Josef Wittgenstein's philosophy of human epistemology and Ernst Troeltsch's understanding of event narration. These three writers validly highlight one of the important facets of human understanding, which in many respects is moulded on prior experience and existing memory. It is no surprise then that both historical and biographical authors typologically recall prior concepts, persons or events to communicate their message. Documents from the ancient Near East frequently reconstruct history on the basis of prior memory. In one place, the invasion of Babylon by the Seleucids, is described in similar language to the Guti invasion of Ur and the corresponding lament expressed by Samaria. In regard to GraecoRoman literature, there was even a technical term for biographical comparison, oúrkpioıs. In one such case Porphyry esteems Pythagoras by noting his Odyssean features and Socratic disposition. It thus seems that Matthew is on sure ground in drawing on Israel's prior traditions and experiences, and contemporaneously re-appropriating them in regard to the material relating to the temple's destruction.

In this process, Matthew portrays Jesus as a thoroughgoing Hebrew prophet, including, 1) the specific terminology in Jesus' speech or that of his interlocutors $(16: 13-16 ; 21: 11,23-27,46$; two of which are uniquely Matthean), and 2) prophetic symbolic actions of the OT (Hosea, Jeremiah and Ezekiel) in shaping the narratives of both the Temple incident and the Fig Tree, both of which were seen to have strong overtones of prophetic denunciation.

Thus we conclude that, within the Matthean narrative, the $\beta \delta$ ć $u_{\gamma} \mu \alpha$ (abomination) refers to Israel's covenantal infidelity, particularly her rejection of Jesus as Messianic King, and the

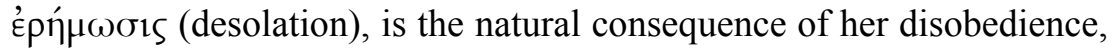
in this case Yahweh's punishment of Jerusalem through Roman intervention. 